\title{
THE RELATIVE CONTRIBUTION OF ALTERNATIVE CAPITAL FLOWS TO SOUTH AFRICA: AN EMPIRICAL INVESTIGATION
}

\author{
Omolola Adeola* \\ Stellenbosch University
}

Received: January 2016

\author{
Meshach Aziakpono" \\ Stellenbosch University
}

Accepted: May 2016

\begin{abstract}
The need for external capital flows to developing countries to supplement domestic savings for investment and growth cannot be over-emphasised, especially in Africa, where there are high levels of poverty and low domestic capacity to save. To achieve sustainable economic growth, countries require other sources of capital from outside the domestic economy. This study uses co-integration and error correction modelling techniques together with tests for weak exogeneity to analyse the effects of four major capital flows into South Africa. This is done for the period 1970 to 2012 in order to determine the relative contribution of these capital flows to South Africa's economic growth. The results reveal that foreign direct investment and remittances had a positive and significant impact on South Africa's economic growth during the period investigated. Debt liabilities and portfolio equity, however, were not statistically significant in terms of their contribution to economic growth.
\end{abstract}

Keywords

Capital flows, economic growth, South Africa, co-integration, foreign direct investment, remittances, economic systems

* Mr O Adeola is a PhD fellow at the University of Stellenbosch Business School (USB), Stellenbosch, South Africa.

\#Prof M Aziakpono is professor at the S University of Stellenbosch Business School (USB), Stellenbosch, South Africa. [meshach.aziakpono@usb.ac.za] 


\section{INTRODUCTION}

It has been observed that most countries in Africa have low growth rates in spite of liberalisation efforts to attract foreign capital flows to achieve sustainable economic growth. Prior to 1994, South Africa was excluded from receiving foreign capital flows from the international community due to its highly controversial and widely criticised apartheid policies. South Africa is, however, still recovering from almost 50 years of apartheid rule and has accordingly adopted policies aimed at attracting foreign capital. As a result, the country has experienced an increase in foreign capital flows, with annual economic growth averaging between $2.35 \%$ and $5.6 \%$ for most years since the transition to popular democracy, except in 1998 and 2009 after suffering from the effects of the Asian and global financial crises respectively. In the past three years, South Africa has experienced a downward trend in its growth level of $1.52 \%$ in 2014 (World Bank WDI, 2015), which may partly be attributed to the effect of capital flows.

Although many studies on capital flows exist, most have concentrated on individual capital flows, with foreign direct investment (FDI) taking centre stage. Research has largely not, however, been directed towards which capital flow specifically contributes most to a particular country. In turn, and because countries are not homogeneous, this might mean that the capital flows attracted are not having the required effect like contributing to economic growth, as they have different effects on different countries (Aizenman, Jinjarak \& Park, 2013: 373-374). Therefore, capital flows should not be generic for all African countries, but tailored to suit the needs and structure of each particular country and its economy. An underlying issue that has not yet been carefully considered is whether all the foreign capital attracted has truly contributed positively to economic growth. It is important to determine this and identify the best form of external capital and attract it to South Africa to improve its economic growth.

Against this backdrop, the main aim of this study is to investigate and determine the effect of foreign capital flows (FDI, portfolio equity, debt liabilities and remittances) on the economic growth of South Africa from 1970 to 2012 to determine which particular capital flow benefits the economy most. As much as it is important to know the contribution of each foreign capital flow to the economy, it is even more important to know the relative contribution of each one to economic growth such that policymakers in South Africa can know which is best to target.

In the next section, we look at foreign capital flows in the context of South Africa. Section 3 provides the theoretical framework and reviews existing literature relating to this study. Section 4 presents the econometric procedure employed in the analysis, while section 5 presents and discusses the results. Section 6 summarises the findings and concludes the paper with some recommendations.

\section{SOUTH AFRICA'S FOREIGN CAPITAL FLOWS}

Historically, South Africa has gone through different regimes, which may be broadly categorised under apartheid and post-apartheid eras. Prior to 1994, South Africa was excluded from receiving financial support due to the economic sanctions imposed by the international community during the apartheid regime. However, following 1994 there was an increase in foreign capital into the country. It was during the first democratic period that official development assistance (ODA) started entering the country. The trend in capital flows to South Africa such as FDI and portfolio equity has consequently increased since the early 1990s, as illustrated in FIGURE 1. 


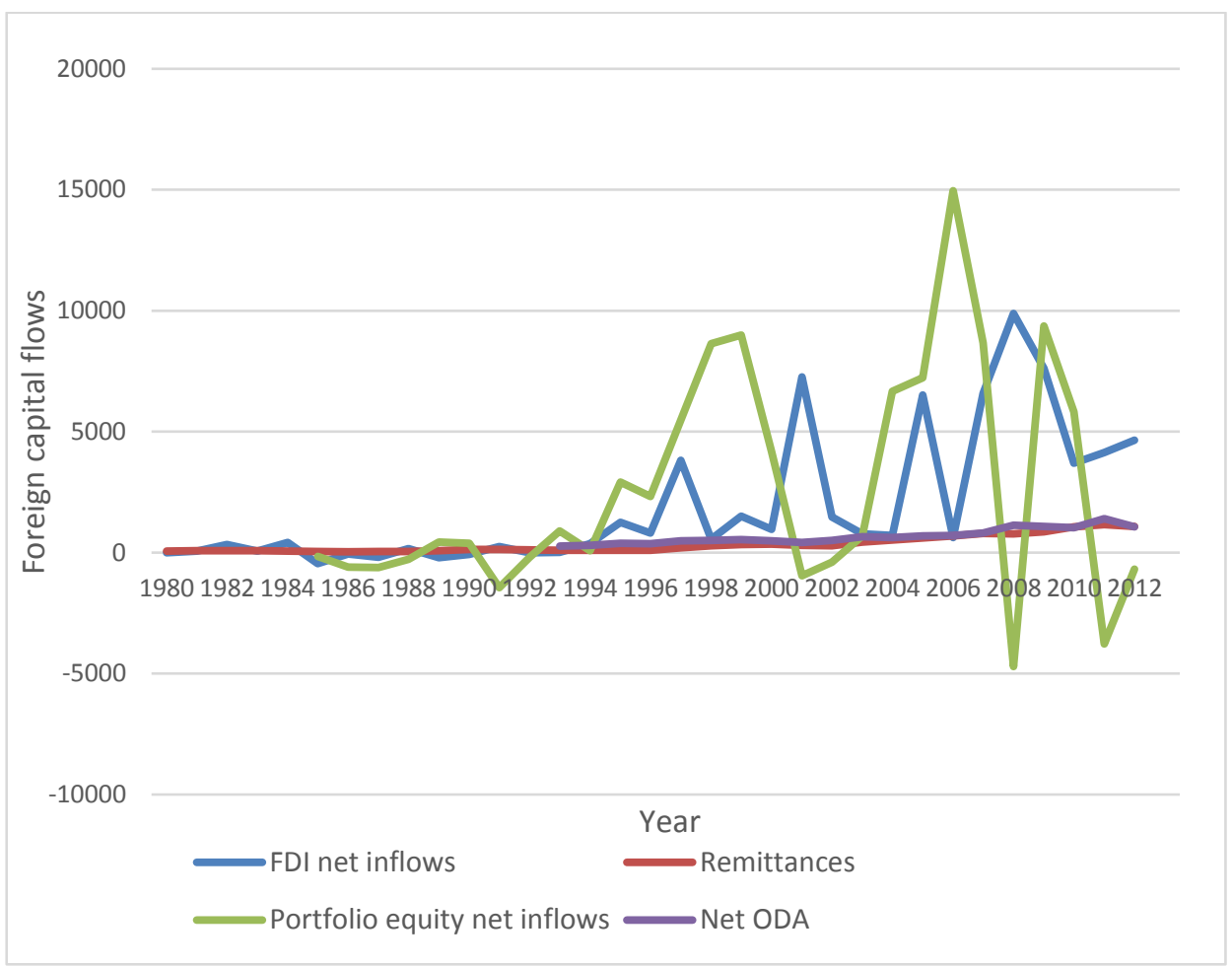

\section{FIGURE 1: $\quad$ Selected Foreign capital flows to South Africa in current US\$ million}

Source: $\quad$ Authors' calculations based on World Bank WDI database 2014

There has been an increase in net inflows of portfolio equity over the years with an increase from about $0.303 \%$ of gross domestic product (GDP) in 1993 to about $2.766 \%$ of GDP in 1999. This represents the highest flow of portfolio equity received so far in sub-Saharan Africa (SSA), with South Africa being the largest recipient in the region (World Bank, 2011). Portfolio equity dropped sharply between 2000 and 2002 as a result of the terrorist attack on the World Trade Centre (WTO) in the United States of America (USA) before regaining momentum towards 2002, peaking at around $2.21 \%$ of GDP in 2006 .

After the 2007 financial crisis in the USA, SSA witnessed a sharp reversal of the inflows of portfolio equity, with a loss of about US $\$ 5.69$ billion (about $0.569 \%$ of GDP) in 2008. Portfolio equity in the region staged a significant recovery during the latter part of 2008 through to mid-2010, with portfolio equity rebounding from a low of minus US $\$ 4.706$ billion in 2008 to minus US $\$ 0.679$ billion in 2012. Africa is witnessing a downward trend due to the effects of the sovereign debt crises in the Eurozone (IMF, 2012). South Africa is the largest recipient of portfolio equity in SSA and therefore is typically affected notably by changes in the level of portfolio equity to the region.

In 2012, FDI flows to South Africa increased to an estimated US\$4.643 billion, after declining sharply in 2010 from an estimated US\$9.885 billion in 2009 to US\$3.693 billion after the global financial crisis. The decrease in portfolio equity in 2008 also coincided with the global financial crisis. This highlights the volatility associated with equity flows during periods of economic shock. The business climate has, however, improved since and favourable economic prospects are 
attracting investment capital flows into the South African economy. Remittances, on the other hand, have continued to increase in South Africa, reaching a high of US\$1.084 billion in 2012, which is an increase of $276 \%$ from the US\$0.288 billion recorded in 2002 (World Bank, 2014).

Historically, South Africa has had a fairly high and positive economic growth for most years, but just before the advent of the first democratic regime in 1994 the country experienced negative growth as illustrated in FIGURE 2. South Africa also experienced a low level of growth in 1999 mostly due to the aftermath of the Asian financial crisis, where the country witnessed a net outflow of R2.7billion in 1999 (Wesso, 2001). Economic growth picked up in the early 2000s, but negative growth was again experienced in 2009 , this time mostly as a result of the global financial crisis. The economic growth rate rose in 2010 and 2011 , the years immediately following the global financial crisis, but in the last three years we have seen low growth of $2.22 \%$ of GDP in $2012,2.21 \%$ in 2013 and $1.52 \%$ in 2014 (World Bank, 2015). This is below the potential growth rate of the economy, particularly seeing that it had been growing at an average rate of over $4 \%$ over the previous decade.

The economic growth below the potential of the economy was accounted for by two industries mining and utilities (electricity, gas and water) (ALMB, 2014). Poor growth performances stemming from these sectors were attributed to domestic conditions such as prolonged and persistent labour unrest (particularly strikes by the mine workers) and the ongoing power crisis (reduction in energy supply and generating capacity) amid persisting challenges brought about by the recent global economic meltdown (RSA, 2014).

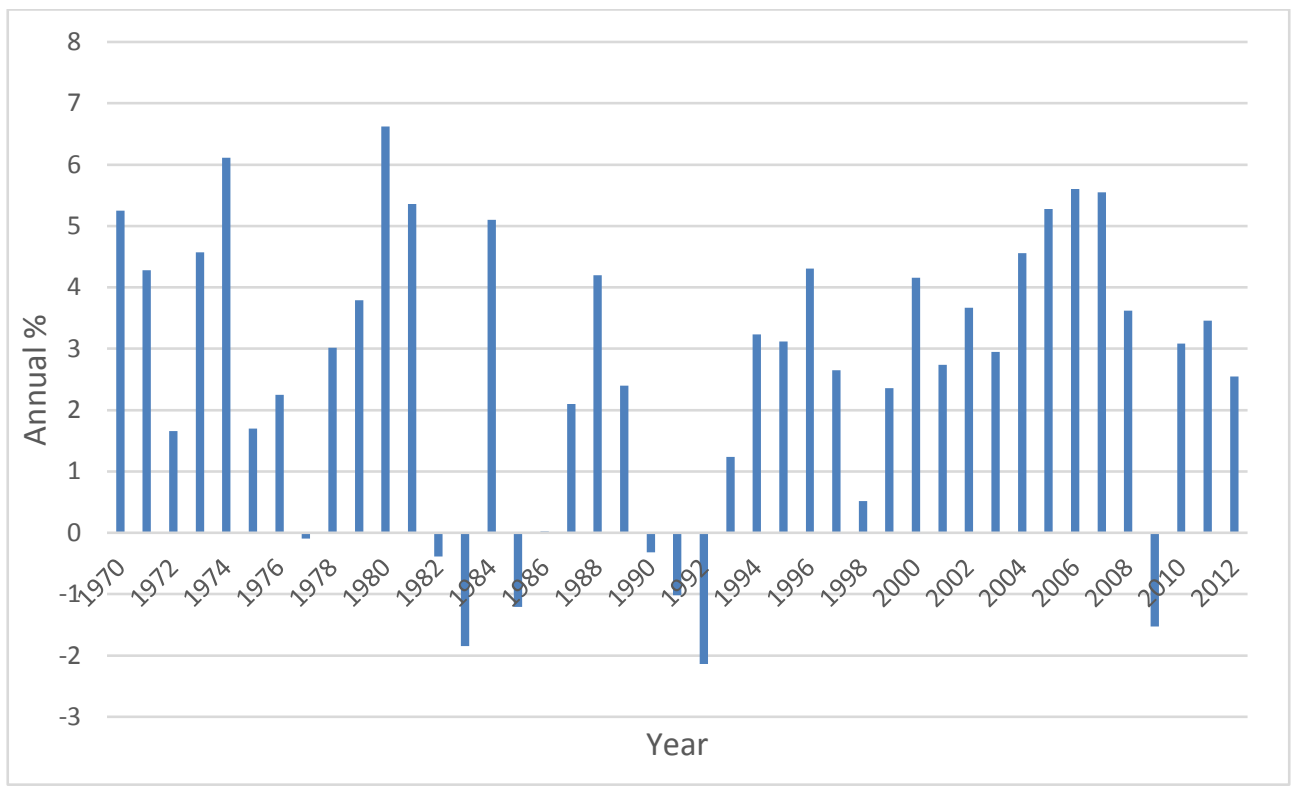

\section{FIGURE 2: $\quad$ GDP growth rate in South Africa (1970-2012)}

\section{Source: $\quad$ Authors' calculations based on World Bank WDI database 2014}

Another way to view the growth performance of the South African economy is based on the three main sectors of the economy (primary, secondary and tertiary). The sectoral composition shows that the tertiary sector's contribution to GDP has been on the increase (from $60.4 \%$ of GDP in 1994 
to $72.7 \%$ in 2013) since the transition to democracy (TABLE 1). The other two sectors, however, concomitantly show a dwindling percentage composition to GDP.

TABLE 1: Sectoral composition of GDP at constant 2005 prices

\begin{tabular}{llll}
\hline Sectors & 1994 & 2004 & 2013 \\
\hline Primary & $11.9 \%$ & $10.4 \%$ & $7.3 \%$ \\
Secondary & $27.7 \%$ & $24.7 \%$ & $20.0 \%$ \\
Tertiary & $60.4 \%$ & $64.9 \%$ & $72.7 \%$ \\
\hline
\end{tabular}

Source: Culled from Du Plessis \& Smit (2006) and ALMB (2014)

In addition, the recent withdrawal of funds from the economy, most notably in the form of disinvestments in portfolio equity, bonds, foreign direct investment (FDI) and official development assistance (ODA), may have resulted in the low level of economic growth and are consistent with rapid drops in the stock market, as investors withdrew $\$ 6.1$ billion from South Africa in 2008 (Macias \& Massa, 2009). The depreciation in the exchange rate of the rand in 2013, dropping to then-low levels of R1l to US\$1 towards the end of the year and the beginning of 2014, may also be attributed to the drop in the stock market and capital outflows. The average official exchange rate has been rising significantly in recent years, with a record R10.85 to US\$1 2014, which was the highest so far (World Bank, 2015), but the record for 2015 has surpassed this value. The rand was initially stronger than the dollar in the 1970s, with the average official exchange rate less than a dollar until 1981. As at 1994, the rate stood at R3.55 to the dollar and has been depreciating ever since, partly due to the effects of new policies on capital flows and trade with the international community. The rand reached an all-time low of R16.84 to the dollar in January 2016 (Trading economics, 2016) and it is still on the verge of further depreciation. The present low trading value of the rand can be linked to an increase in the country's current account deficit, low savings, low GDP growth and ongoing developments with its main trading partners, such as the recent devaluation of the Chinese yuan. Again, the abrupt removal of the Minister of Finance (Nhlanhla Nene) in December 2015 might also have contributed to the present depreciation of the rand to the dollar, as there were mixed views about his removal. The xenophobic attacks in South Africa might also be a deterrent to investors, as this will send signals of insecurity to the outside community. This might also contribute to a reduction in economic growth.

Considering the low level of economic growth in the country and the present challenges of poverty, inequality and unemployment, there is a need to embark on various measures to improve economic growth to combat these prevailing challenges. This issue was highlighted by the South African president during the first state of the nation address of the fifth democratic administration delivered on 17 June 2014. He stated that the most effective weapon in the campaign against poverty is to achieve faster economic growth through the creation of more employment opportunities in the economy. He further stated that an annual growth rate of $5 \%$ is the target from 2019; therefore there is the need to adopt feasible measures and actions to spur the economy to higher growth rates.

If South Africa is expected to meet the target of $5 \%$ GDP growth rate as at 2019 , there is a need to focus on the capital flow that contributes the most to the economy. For a country to achieve an increase in productivity and output, theoretically capital is an important tool. A decrease in domestic savings has been observed from 1980 from $37.89 \%$ of GDP to $16.36 \%$ in 2012 . This reflects the need for foreign capital to augment domestic savings to sustain and increase investment. 
A preliminary investigation was performed using simple correlation, which shows capital flows were low before the democratic regime but relatively high thereafter except for portfolio equity (TABLE 2). The decade-by-decade analysis shows no record of debt liabilities, and ODA before the 1990 s and all the capital flows reflect a low correlation to GDP per capita in the 1990s. Portfolio equity showed a very low correlation with GDP per capita over the entire period, while ODA, remittances and FDI were the most correlated with GDP per capita, especially since the move to democracy. With this background, we explore the theoretical framework on which this study is based in the next section.

TABLE 2: Correlation of foreign capital flows and GDP per capita from 1970 - 2014 in SA

\begin{tabular}{cccccc}
\hline GDP percapita & FDI & Portfolio Equity & Debt Liability & Remittances & ODA \\
\hline $1970-1979$ & -0.1900 & - & - & 0.7442 & - \\
$1980-1989$ & 0.4846 & 0.4597 & - & 0.6473 & - \\
$1990-1999$ & 0.0650 & -0.1307 & 0.2994 & 0.0201 & 0.5807 \\
$2000-2009$ & 0.5676 & 0.3203 & 0.4128 & 0.9701 & 0.9022 \\
$2010-2014$ & 0.7479 & -0.4060 & 0.1964 & -0.5646 & 0.4560 \\
Total & 0.5680 & 0.0268 & 0.5235 & 0.7078 & 0.9353 \\
$1970-1993$ & 0.0860 & 0.0416 & - & -0.2118 & - \\
$1994-2014$ & 0.6619 & -0.0970 & 0.1039 & 0.9583 & 0.9301 \\
\hline
\end{tabular}

Source: Authors' calculations from World Bank WDI 2015

\section{LITERATURE REVIEW}

\subsection{Theoretical framework}

This study employs the endogenous growth model - the 'AK model' used by Pagano (1993) and its extended form by Bailliu (2000: 5-8), who introduced international capital flows to capture the relationship between foreign capital flows and economic growth. Here, the aggregate output is a linear function of the aggregate capital stock:

$$
Y_{t}=A K_{t}
$$

where the above is a typical growth function, $Y_{t}=$ aggregate output in time $t, K_{t}=$ capital stock in time $t$ which is a combination of both physical and human capital; and $A=$ marginal productivity of capital (MPK). We make certain assumptions: ( $i$ ) the population is constant; and (ii) the economy produces a single good, which can either be consumed or invested. If invested, the capital stock depreciates at the rate of $\delta$ per period, and then gross investment is given by:

$$
I_{t}=K_{t+1}-(1-\phi) K_{t}
$$

However, the transmission of savings into investment requires financial intermediaries where a proportion of savings $(1-\phi)$ is taken as a reward for services offered. The proportion of savings left is equal to investment in the capital market equilibrium state in a closed economy given by: 


$$
\phi S_{t}=I_{t}
$$

The growth rate of output, $g$, from equations (1) to (3) without the time indices is given by:

$$
g=A\left(\frac{1}{Y}\right)-\delta=A \phi S-\delta
$$

Where $s$ = gross saving rate. Equation (4) is the steady-state growth rate of a closed economy.

From the above one can see that financial development has an impact on economic growth through financial intermediaries effectively allocating savings for investment. The expertise of banks, through increased intermediation, results in a reduction of the spread between lending and borrowing rates, which in turn leads to an increase in the proportion of savings invested. In turn, this leads to an increase in $g$ through the increase in $\phi$ from equation (4). In addition, financial intermediation allocates capital to more productive investments and channels funds to investments where there is higher marginal productivity of capital, thereby leading to higher growth.

The above framework is extended to integrate foreign capital flows and accordingly draws on the work of Bailliu (2000) and Aziakpono (2008). The closed economy assumption will be relaxed here to allow for the free movement of capital into and out of the domestic economy. The above equilibrium conditions can be modified to adjust for the effects of foreign capital flows thus:

$$
\phi^{*}\left(S_{t}+F C F_{t}\right)=I_{t}^{*}
$$

Where $F C F_{t}$ is the net foreign capital flows and * represents an open economy. The new steadystate growth rate can be represented as:

$$
g^{*}=A^{*} \frac{I^{*}}{Y}-\delta=A^{*} \phi^{*} \frac{S+F C F}{Y}-\delta=A^{*} \phi^{*} s^{*}-\delta
$$

In the absence of any friction, the model suggests an increase in capital flows to the developing country $\left(F C F_{t}>0\right)$, which will help to augment domestic savings $\left(s^{*}>s\right)$. In a situation where the foreign capital inflow is invested productively and is not consumed, the level of domestic investment in the developing country will rise, which will lead to an increase in economic growth $\left(g^{\star}>g\right)$.

Since the different capital flows contribute differently to economic growth, we highlight the different ways below.

\subsubsection{Foreign direct investment}

Positive effects of FDI on economic growth occur directly by increasing the stock of physical capital in the recipient country as foreign capital is accumulated indirectly by encouraging human capital development and strongly boosting technological upgrading. FDI also leads to growth through capital accumulation through (a) the existence of foreign technology and new inputs in the host country's production function, and (b) knowledge transfers, which increase existing knowledge in the host economy through labour training and skill acquisition, and through the introduction of alternative management practices and organisational arrangements (De Mello, 1997: 8-10). FDI may, however, affect growth negatively should the presence of foreign firms reduce the productivity of domestically owned firms, especially in the short run with no technology spillover, whereas in the long run, labour mobility may occur and lead to spillover effects (Aitken 
\& Harrison, 1999:607). If FDI is concentrated in a specific sector, it might not have spillover effects.

\subsubsection{Foreign portfolio equity}

Levine and Zervos (1998:537) suggest that liberalising constraints on foreign portfolio flows tend to increase domestic stock market liquidity, which could have a positive effect on productivity and, ultimately, economic growth. On the other hand, the effect of this could be negative on both the economy and households through various channels, since large financial shocks that result in a sudden reversal of capital flows can lead to a sharp depreciation in the exchange rate, imports becoming more expensive, and rising prices for food and basic amenities, which will invariably weaken purchasing power (Demirgüc-Kunt \& Levine, 1996:230).

\subsubsection{Foreign debt flows}

According to Pattillo, Poirson and Ricci (2002: 4-6), there are different theories on foreign debt flows and economic growth. One theory suggests that a rational level of debt is expected to have a positive effect on growth, while another posits that large accumulated debt stocks may be a deterrent to growth. The third theory combines these two postulations. Ajayi and Oke (2012: 299) used the dual-gap theory or two-gap approach developed by Chenery and Strout (1966) to explain how foreign debt leads to economic growth. The dual gap analysis shows that development is a function of investment and that such investment, which requires domestic savings, is not sufficient to ensure that development takes place. Foreign capital features where there is a savings-investment gap and where an import-export exchange gap exists. The excess of investment over domestic savings is said to be equivalent to the surplus of import over export. This is then where the maximum level of import required to meet growth targets is higher than the maximum level of export. This has also been used to explain foreign aid.

\subsubsection{Foreign aid}

Foreign aid is usually used to fill in gaps in the economy, and the two-gap model specified in Easterly (2003: 30-31), developed by Chenery and Strout (1966), has been employed to explain the link between foreign aid and economic growth. Morrissey (2001) identified a number of mechanisms through which aid can contribute to economic growth, namely: aid increases investment in physical and human capital stock; aid increases the capacity to import capital goods or technology; and aid is associated with technology transfer, which increases the productivity of capital and promotes endogenous technological change. The general theory behind the aid-growth theory is that physical capital leads to growth.

\subsubsection{Remittances}

Remittances generally help to develop financial markets, finance entrepreneurial activities, act as insurance against shocks, finance household expenditure and household human capital formation, and bridge savings and external financing gaps. This would lead to an increase in growth. The literature has grouped migrant remittances into two main components, namely the endogenous migration approach and the portfolio approach (Elbadiwi \& Rocha, 1992; Chami, Fullenkamp \& Jahjah, 2005). The endogenous migration approach is based on the economics of the family, which includes but is not limited to motivations based on altruism. The portfolio approach isolates the decision to remit from the decision to migrate, and as such does not take 
into consideration issues of family bonds. According to the portfolio approach, the migrant earns income and decides how to allocate savings between host- and home-country assets. Remittances from the portfolio approach therefore stem from the decision to invest in homecountry assets. The portfolio view is a theory of remittances that supports the view that remittances behave like other foreign capital flows. The effect of remittances could also be negative on the economy if they lead to an appreciation in the exchange rate (Amuedo-Dorantes \& Pozo, 2004: 1410-1411).

\subsection{Empirical literature review}

The ongoing theory of foreign capital flows and economic growth has attracted several empirical studies that grapple with this issue (Levine \& Zervos, 1998; Bailliu, 2000; Reisen \& Soto, 2001; Chinn \& Ito, 2006; Klein \& Olivei, 2008; Aizenman et al., 2011). The observed effects are often inconclusive and these studies generally tend to find conflicting results. The review of available literature pertaining to these issues by Kose, Prasad, Rogoff and Wei (2009) emphasises the inconsistency in the literature and the general disparity and inconclusiveness of this ever-growing body of literature. Some researchers believe capital flows would improve developing countries' growth (King \& Levine, 1993; Bailliu, 2000; Edison, Levine, Ricci, \& Sløk, 2002; Aizenman et al., 2011), while others have argued that foreign capital has a negative effect on growth (Murshid \& Mody, 2011).

An examination of the global literature on the topic reveals that most studies devoted attention to one particular form of foreign capital inflow or the other, with results ambiguous and inconclusive. Very few attempts have actually been made at comparing the effects of the various capital flows' contributions to economic growth, with the exception of studies by Reisen and Soto (2001), Aizenman et al. (2011), and Driffield and Jones (2013). Studies on FDI are numerous, with most observing positive effects, while some identify both requisite preconditions and prevailing policies for FDI to be effective (Balasubramanyam, Salisu \& Sapsford, 1996; Borensztein, De Gregorio \& Lee, 1998; Bengoa \& Sanchez-Robles, 2003; Alfaro, Chanda, Kalemli-Ozczn \& Sayek, 2004; Adjasi, Abor, Osei \& Nyavor-Foli, 2012). Still others found negative effects between FDI and economic growth (Carkovic \& Levine, 2002; Lensink \& Morrisey, 2006). Among the literature on portfolio equity investment, Demirgüc-Kunt and Levine (1996) and Quinn and Toyoda, (2008) found positive impacts on economic growth, while Durham (2004) and Agbloyor, Abor, Adjasi and Yawson (2014) found negative impacts. Empirical literature on debt flows generally shows more of a negative contribution to economic growth (Ndikumana \& Boyce, 2003; Adegbite, Ayadi \& Ayadi, 2008; Akram, 2013) than a positive one, with certain thresholds, once breached, indicating that debt flows' effect on economic growth then becomes negative (Fosu, 1996; Checherita \& Rother, 2010; Reinhart \& Rogoff, 2010; Baum, Checherita-Westphal \& Rother, 2013). While foreign aid has been observed to have positive effects on economic growth (Papanek, 1973; Hansen \& Tarp, 2001; Karras, 2006; Asteriou, 2009), generally with certain conditions in place, some studies have found negative effects (Mosley, Hudson \& Horrell, 1987; Rajan \& Subramanian, 2008), with the most recent studies emerging after the work of Burnside and Dollar (2000) on 56 developing countries. With remittances, the majority of studies observed a positive impact on growth (Fajnzylber \& Lopez, 2007; Acosta, Calderon, Fajnzylber \& Lopez, 2008; Giuliano \& Ruiz-Arranz, 2009; Fayissa \& Nsiah, 2010; Chowdhury, 2011; Lartey, 2013), while a few studies observed negative effects (Amuedo-Dorantes \& Pozo, 2004; Buch \& Kuckulenz, 2004; Chami et al., 2005; Barajas, Chami, Fullenkamp, Gapen, \& Montiel, 2009). 
Since most studies on capital flows have used cross-sectional and panel analysis, which does not allow for country-specific differences in the estimation, we concentrate on the few studies on South Africa time series analysis that cater for the flaws of the above-mentioned estimation analysis. The study by Wesso (2001) on net capital flows and the real GDP growth rate using error correction technique and unrestricted VAR on quarterly data from 1991:1 to 2000:4 revealed a negative relationship between net capital flows and relatively high domestic inflation rates, but a positive effect on economic growth in the long run. Tswamuno, Pardee and Wunnava (2007) also observed the relationship between real per capita GDP and capital account liberalisation using the ordinary least square (OLS) estimation technique on quarterly data from 1975:3 to 2005:1. They found that while post-liberalisation foreign portfolio investment (FPI) had no positive effect on economic growth, increased post-liberalisation stock market turnover had a negative effect on economic growth in South Africa. The study by Fedderke and Romm (2006) looked at the growth impact and determinants of FDI into South Africa. They found that FDI is capital intensive and has a positive impact on economic growth using Johansen-VECM specification on annual data from 1960 to 2002. Dzangare (2011) also investigated the relationship between private capital flows (FDI, bank lending, equity and bonds) on real GDP growth using quarterly data from 1989:4 to 2009:4. A positive relationship was observed between private capital flows and real GDP growth, also adopting the Johansen co-integration technique.

A closely related work is by Aziakpono (2008), which is a comprehensive study of financial integration and financial development on economic growth for Southern African Customs Union (SACU) countries using capital flows as measures of financial integration. The study explored the relationship between $\mathrm{FDI}$, debt liabilities and portfolio liabilities, and the economic performance of South Africa from 1970 to 2004 using the Johansen co-integration and VECM estimation. A statistically significant and positive relationship was observed mostly for FDI and portfolio equity, while debt liabilities showed robust evidence of a negative and statistically significant relationship with economic performance in South Africa.

The data employed in the study by Aziakpono (2008) included data for 2004 but not beyond, whereas this study covers more capital flows over an extended period until 2012, thus covering the period of the global financial crisis which might have an impact on the capital flows in the country. This study seeks to address issues not considered in previous studies on South Africa and, more importantly, to show the relative contribution of capital flows to economic growth such that South Africa can know which specific capital is best to attract through tailored policies. The next section provides the empirical analysis, which specifies the model and highlights the econometric procedure followed.

\section{EMPIRICAL ANALYSIS}

\subsection{Data and methodology}

This study employs annual data obtained mostly from the World Bank's World Development Indicators (WDI) database and the World Bank's Global Financial Development Database (GFDD). Data on some of the capital flows (CFs), such as the stock of FDI, portfolio equity and debt liabilities, was obtained from the updated Lane and Millesi-Ferretti (LMF) dataset - External Wealth of Nations Mark II: Revised and updated 1970 to 2011. This period was chosen to capture the period of increased capital flows to South Africa and allow a sufficient period for time series observation. Official development assistance (ODA) was dropped from the analysis, as there was 
an insufficient number of observations to conduct a meaningful and reliable estimation, since South Africa did not start receiving ODA until the post-apartheid era in the early 1990 s.

GDP per capita is used as a proxy for economic growth, with four capital flows and nine control variables. The capital flows are all expressed as a percentage of GDP and converted to natural logarithm (LN) form with the exception of remittances, which were not expressed in LN form due to their small scale. All the control variables (CVs) are in their LN form. The capital flows used in the estimation are foreign direct investment liability stock (FDIS), portfolio equity liability stock (PES), debt liability stock (DLS) and remittances (REM). The explanatory variables used are the standard growth determinants obtained from the literature, which include gross fixed capital formation as a proxy for domestic investment (DI), inflation (consumer prices) (INF) and real effective exchange rate (REદR), both of which were included for macro-economic instability, general government final consumption expenditure (GC), exports of goods and services (EXP), imports of goods and services (IMP), openness to trade - the sum of imports and exports - (XM), liquid liabilities (M3) as a percentage of GDP as a measure of financial development (FD) and private credit by deposit money banks to GDP (PC).

\subsection{Model specification and analytical framework}

A multivariate vector error correction model is specified following Zhou (2003) and Aziakpono (2008). The model is limited to three variables, thus using a trivariate model to avoid the problem of loss of degree of freedom where $X_{t}=f(y, C F, C V)$. The measure of economic growth is constant in all the models denoted as $Y$. The measure of the four different capital flows, namely debt liability (LNDLS), foreign direct investment (LNFDIS), portfolio equity (LNPES) and remittances (REM) is alternated and used with a single control variable at each time. The control variables are log of domestic investment (LNDI), log of exports (LNEXP), log of financial development (LNFD), log of government consumption (LNGC), log of imports (LNIMP), log of inflation (LNINF), log of private credit (LNPC), log of real effective exchange rate (LNREER) and log of openness to trade (LNXM).

By way of example, in addition to the measure of economic growth, in the model represented as LNYPCK, a capital flow (CF) was included starting with the log of debt liability stock (LNDLS) and with each of the control variables being introduced one at a time until all nine control variables have been used in a model individually. Then the capital flow was changed, in this case to log of foreign direct investment stock (LNFDIS), and all the control variables were worked through until all the capital flows and control variables had been combined.

To compare the result, the effect of each of the measures of capital flows was observed to determine which has the highest and strongest impact on economic growth. The effects of the control variables are used to interpret the results and answer the research question; however, the emphasis is not on the control variable but on the capital flow variables.

\subsection{Econometric procedure}

Since the study deals with time series data, the data generating process of the variables could affect the model. Therefore the starting point of the analysis is to test the variables for unit root to determine the order of integration. If the variables are not in the same order, they could affect the performance of the model. For instance, if all the variables are stationary at level, the analysis would automatically lend itself to a vector autoregressive (VAR) model. On the other hand, if the 
series are not stationary at level, i.e. I ( 0 ), but stationary at $\mathrm{I}^{\text {st }}$ difference, $\mathrm{I}(\mathrm{l})$, then the Johansen co-integration technique is applied to determine if they have a long-run relationship.

There are several methods of testing for unit root in the literature. For the purpose of this study, three methods are used, namely two unit root tests (the Augmented Dickey-Fuller (ADF) and NgPerron) and a stationarity test (Kwiatkowski-Phillips-Schmidt-Shin (KPSS)) to ensure robustness of the results. One potential problem this could create is where there is conflict between the results, but if one of the tests suggests there is unit root, it is used as such. The data generating process could present a trend, intercept or no trend or intercept in the series. Hence, the ADF test would be used for each of the series at level to determine whether there is intercept, stochastic trend or deterministic trend according to Seddighi, Lawler and Katos (2000).

If the result shows the series are not stationary at level, but at $1^{\text {st }}$ difference, then the cointegration test is conducted to determine whether or not a long-run relationship exists among the variables. There are a number of co-integration test methods that can be used, for example the single equation method or the maximum likelihood test proposed by Johansen and Jesulius (1990). The latter was used given that there are more than two variables in the model. The maximum likelihood test is more suitable for the multivariate system, since it enables researchers to determine if there is more than one co-integrating relationship. The Johansen maximum likelihood method is preferred over the Engle Granger single equation method, as the Engle Granger has poor small sample properties and has no correction for simultaneous equation bias (IMF, 2003).

If there is a long-run relationship between economic growth and capital flows, the vector error correction model (VECM) would be used for the analysis. The Johansen co-integration test was done by first determining the lag order of the VAR. The lag selection was set at a maximum of eight to allow for a wide degree of freedom considering the number of observations used. The sequential modified likelihood ratio (LR) test statistic, final prediction error (FPE), Akaike information criterion (AIC), Schwarz information criterion (SC) and Hannan-Quinn information criterion (HQ) were relied upon to determine the appropriate lag order. The lag indicated was then tested for serial correlation using the VAR Residual Serial Correlation LM tests. The lag used for the cointegration was one that produced no serial correlation and was tested starting from the minimum lag indicated by the lag order selection criteria to a maximum of four lags. The deterministic test assumption used was based on the result of the ADF unit root test where a variable either had intercept, a stochastic trend or a deterministic trend. According to the $\varepsilon$-views 8 manual, deterministic trend assumption of test has five options. Option 1 is used where the level data has no intercept or trend in the co-integrating equation. Option 2 is used where there is intercept but no trend in the co-integrating equation. Option 3 allows for a linear deterministic trend in the data and is used where there is intercept but no trend in the co-integrating equation. Option 4 also allows for a linear trend in the data and is used where there are both intercept and trend in the co-integrating equation. Option 5 allows for a quadratic deterministic trend in the data and is used where there are both intercept and trend in the co-integrating equation. Since all the models estimated were a trivariate model, the assumption was based on the most dominant. In cases where all three variables had neither intercept nor trend, stated as none, assumption 2 was used. Where at least one of the variables had an intercept but no trend, assumption 3 was used. In cases where one of the three variables had a deterministic trend, assumption 4 was used in the estimation. 
In order to carry out the Johansen co-integration test, two test methods are usually used. They are the trace statistics and the maximum eigenvalue proposed by Johansen (1988; 1991), with their test statistics as follows respectively:

(ii) maximum eigenvalue statistics $\left(\lambda_{\max }\right)=-\left\lceil\log \left(\mathbf{1}-\hat{\boldsymbol{\lambda}}_{r+\mathbf{1}}\right)\right.$

Where $\hat{\lambda}_{\boldsymbol{i}}$ is the $t^{\text {th }}$ largest eigenvalue of the $\Pi_{i}$ matrix of the equations above. P values were employed to test for co-integration and the null hypothesis of $r=0, r=1$ and $r=2$ were tested sequentially from low to high values of $r$. The sequential testing was conducted until the null hypothesis was not rejected for the first time. In a situation where trace statistics and maximum eigenvalue statistics did not agree on the number of co-integrating equations, the decision to rely on either statistic was based on the most reliable from economic reasoning. Where no cointegration was found after testing with lag lengths up to lag 6, the models were not reported.

The existence of a long-run relationship in the model suggests there would be causality at least running from one variable to the other. In other words, the direction of causality would be determined. This is done using the weak exogeneity test in the vector error correction model (VECM) framework. The weak exogeneity test was carried out following Demetriades and Hussein (1996) and Arestis and Demetriades (1997). Restrictions were placed on each variable within the system to determine which ones are endogenous. In the models reported, the causality between economic growth and the corresponding capital flow was established.

The VECM estimation technique assumes that all the variables are endogenous until tested for weak exogeneity. Where economic growth or capital flow in the model was found to be the endogenous variable, the model was further explored by normalising on the variable that was endogenous as the dependent variable. A normalisation restriction is imposed to identify the true co-integrating vector (Aziakpono, 2008), and each vector is normalised on the variable for which a clear evidence of error correction is found. If economic growth or capital flow is endogenous, then the model is estimated further; however, if only the control variable is endogenous, then the model is not estimated further, as the purpose of this study is not to model the control variable. Economic growth, capital flow or both must be endogenous to determine the causality. Should both be endogenous, it suggests that bi-directional causality exists between the two variables. If economic growth is endogenous, then economic growth is normalised on to find the effect of capital flow on economic growth. Contrastingly, if capital flow is endogenous, then capital flow is normalised on to find the effect of economic growth on capital flow.

The estimation was progressed with the models where either economic growth or the capital flow was endogenous. The slope coefficients were reported after the model was normalised on the endogenous variable. The error correction term was also reported as well as the adjusted $R^{2}$. The model was then tested for serial correlation in the lag length used in the VECM by using the residual serial correlation LM test to ensure no serial correlation of the variables, which might distort the results of the estimations. A heteroscedasticity test was also performed for the model to be qualified as a good model.

\section{EMPIRICAL RESULTS}

The estimation analysis started with unit root tests. The variables were tested for unit root and stationarity. The ADF unit root test results are reported in TABLE 3. It was observed that three 
variables (debt liability, financial development and real effective exchange rate) were stationary at levels I(0). All the other variables used in the estimation were stationary at first difference, $\mathrm{I}(\mathrm{l})$. The alternative test of no unit root, KPSS stationarity test and Ng-Perron unit root test were also conducted to ensure the robustness of the results, but are not presented here. The results of the ADF unit root tests were confirmed by the KPSS test. From this, the Johansen co-integration test can be performed, since most variables are integrated of order one, i.e. I(1). I(0) variables were also included in the analysis, as it has been shown from studies that they might be important in economic theory (Harris, 1995).

The Johansen co-integration test was performed after the lag length selection. The models with co-integration were reported, with most of the models having at least one co-integrating equation. The results of the trace statistics and maximum eigenvalue statistics are not reported due to space constraints. A total of 36 models were estimated, nine for each of the capital flows. Most of the models were found to have at least one co-integrating relation, which shows that a long-run relationship exists between them. Of all the capital flows, it was only portfolio equity model with financial development and private credit as control variables that did not indicate any co-integrating relation and was therefore not reported. All the other measures of capital flows produced co-integrating relations in the models and were accordingly reported.

TABLE 3: ADF Unit root test results

\begin{tabular}{|c|c|c|c|c|c|c|c|}
\hline Series & Period & Model & $\begin{array}{l}\text { Lag } \\
\text { length }\end{array}$ & Level & $\begin{array}{l}\text { Lag } \\
\text { length }\end{array}$ & $\begin{array}{c}\text { Ist } \\
\text { difference }\end{array}$ & $D /$ \\
\hline LNYPCK & $1972-2012$ & None & 1 & 0.815 & 0 & 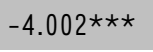 & $I(1)$ \\
\hline LNDLS & $1972-2011$ & Intercept & 1 & $-3.605 \star \star \star *$ & 0 & $-4.940 * \star \star *$ & $I(0)$ \\
\hline LNFDIS & $1971-2011$ & None & 0 & -0.247 & 0 & $-6.937 * \star \star$ & $\mathrm{I}(\mathrm{l})$ \\
\hline LNPES & $1973-2011$ & Trend & 2 & -2.100 & 1 & $-6.691 * \star \star$ & $\mathrm{I}(1)$ \\
\hline REM & $1972-2011$ & None & 1 & 0.295 & 0 & $-3.838 * \star \star$ & $\mathrm{I}(\mathrm{l})$ \\
\hline LNDI & $1972-2012$ & None & 1 & -0.598 & 0 & $-4.197 \star \star \star$ & $\mathrm{I}(1)$ \\
\hline LNEXP & $1971-2012$ & Intercept & 0 & $-2.654 *$ & 0 & 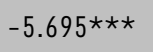 & I(1) \\
\hline LNFD & $1972-2011$ & Trend & 1 & $-4.088 * \star$ & 4 & $-5.929 * \star \star$ & $I(0)$ \\
\hline LNGC & $1971-2012$ & None & 0 & 1.654 & 0 & $-5.258 * \star \star *$ & I(1) \\
\hline LNIMP & $1971-2012$ & None & 0 & 0.208 & 0 & 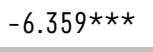 & $\mathrm{I}(\mathrm{l})$ \\
\hline LNINF & $1975-2012$ & $\begin{array}{l}\text { Intercept \& } \\
\text { Trend }\end{array}$ & 0 & $-3.495^{\star}$ & 3 & $-5.717 \star \star \star$ & $\mathrm{I}(1)$ \\
\hline LNPC & $1976-2011$ & Trend & 1 & $-3.518 *$ & 4 & 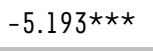 & $\mathrm{I}(\mathrm{l})$ \\
\hline LNREER & $1977-2012$ & Trend & 1 & $-3.596 * \star$ & 1 & 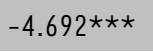 & $I(0)$ \\
\hline LNXM & 1971-2012 & None & 0 & 0.352 & 0 & 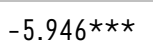 & I(1) \\
\hline
\end{tabular}

Source: Authors' analysis

Notes: $* \star \star *$, and $* \star \star$ - denotes the rejection of the null hypothesis of unit root at $10 \%, 5 \%$, and $1 \%$ level of significance respectively

The results of the weak exogeneity test revealed that the causality between economic growth and capital flow in South Africa is not bi-directional, except for remittances, with two models where the control variables (log of domestic investment and log of government consumption) were 
included. Foreign direct investment showed effect of causality on economic growth in South Africa significantly more than the effect of economic growth on foreign direct investment. The weak exogeneity test results are not reported here for lack of space.

In all the models reported, causality between economic growth and the corresponding capital flow was established. For debt liability, the results suggest that causality runs mainly from economic growth in four of the models tested, compared to a single model that showed causality running from debt liability to economic growth. This indicates that GDP per capita causes debt liability. Foreign direct investment, on the other hand, suggests the opposite, where causality runs generally from foreign direct investment to economic growth in four of the models, compared to one model that showed causality running from economic growth to foreign investment. For portfolio equity, the results show that portfolio equity does not cause economic growth in all the models estimated except for two models, where causality runs from economic growth to portfolio equity. Finally, with regard to remittances, the overall evidence seems to suggest that the causality between economic growth and remittances is mixed, as two of the models indicated bicausality, three indicated causality running from economic growth to remittances and four models indicated causality running from remittances to economic growth.

So far, the evidence shows that a long-run and causal relationship between economic growth and capital flows exists in South Africa. The magnitude and sign of the causal effect was further explored. The slope coefficients of the estimated models are recorded in TABLE 4. The LM statistics from the serial correlation test and the probability are also reported. Where the probability was above the $10 \%$ significance level, which signifies that we cannot reject the null hypothesis of no serial correlation at the chosen lag order, then it was taken that the model had passed the serial correlation test and heteroscedasticity test was performed. Here, the chi-square and probability were reported and the model had to pass this test with a probability above $10 \%$ as well for it to be qualified as a good model. The results reported in TABLE 4 are the models that passed all these tests.

From the results, it can be observed that debt liability and portfolio equity were not statistically significant in determining economic growth. Foreign direct investment and remittances, on the other hand, showed a positive relationship with economic growth in South Africa. The coefficients also showed high statistical significance at the $1 \%$ level. The first panel from TABLE 4 presents the results of the debt liability estimation, which shows that economic growth influences debt flows in South Africa but is statistically insignificant for all the models. The results are, however, mixed as two of the models show a positive relationship and the other two a negative relationship. The degree of elasticity ranges from minus 0.10 to 0.20 and the speed of adjustment to long-run equilibrium ranges from minus 0.24 to minus 0.54 , with most of the model concentrated towards the upper part of the range. This indicates a relatively moderate speed of adjustment. The explanatory power of the model was quite high, with the least value being almost $30 \%$. The models passed all the residual diagnostic tests, thus confirming the validity of the models.

The results suggest that portfolio equity stock does not lead to economic growth, but rather that economic growth causes portfolio equity. Although out of the two models reported for portfolio equity that passed all the tests, one model with the control variable government consumption showed a positive relationship between portfolio equity and economic growth and was statistically significant (although only at the $10 \%$ level), whereas the other model with domestic investment as control variable showed a negative and statistically insignificant relationship.

The elasticity for the insignificant model was minus 2.88 , while that of the significant model was 3.64. The speed of adjustment as indicated from the error correction term (ECM term) was also 
minus 0.09 and 0.21 respectively. The adjusted $R^{2}$ for the two models was barely $20 \%$, indicating the low explanatory power of the models.

Remittances, on the other hand, show evidence of a positive effect of capital flow on economic growth in South Africa. Out of the six models reported, four indicate that remittances lead to economic growth, while the other two show that economic growth leads to increased remittances, but these two models were not statistically significant at all. Of the four models, three show a positive and statistically significant relationship at the $1 \%$ level, with very high elasticities ranging from 0.66 to 0.98 . The error correction term ranges from $1 \%$ to $18 \%$, which shows the speed of adjustment to any changes in equilibrium to be quite low. The last model indicates a negative relationship between remittances and economic growth, with a degree of elasticity of minus 21.50 and a $1 \%$ speed of adjustment to long-run equilibrium. This means there are hardly any changes to economic growth with a shift in equilibrium.

Foreign direct investment also showed a positive and significant relationship at the $1 \%$ significance level with economic growth, with elasticity ranging between 0.19 and 0.98 . The speed of adjustment ranges between minus 0.02 and 0.13 , which is low. This shows that any changes to the long-run equilibrium would not bring about significant correction back to equilibrium in the short term.

The results thus confirm economic theory that FDI contributes positively to economic growth. This is also consistent with the results of most empirical studies on FDI and remittances, namely that they exert more of a positive impact on economic growth than a negative one (Reisen \& Soto, 2001; Driffield \& Jones, 2013). The study further shows that debt liabilities and portfolio equity were not significant in explaining economic growth in South Africa. While the level of portfolio equity in South Africa has been higher than that of FDI over the years, it does not contribute as significantly to economic growth as FDI does. This accordingly provides evidence to suggest that South Africa cannot continue focusing on attracting the wrong type of capital flows. This result contradicts the findings of Dzangare (2011), who found a positive effect of these capitals flows on economic growth in South Africa. This discrepancy in findings may be associated with the model of Dzangare employing a large number of variables that produced four co-integrating equations. However, this was not further explored in his study to identify the equations and normalise on the endogenous variable in the model.

\section{SUMMARY, CONCLUSION AND RECOMMENDATIONS}

The study explored the relative contribution of the major capital flows (foreign direct investment, foreign portfolio investment, debt flows and remittances) in South Africa to economic growth. A causal effect between these capital flows and economic growth was established. Furthermore, the magnitude and sign of the long-run relationship between the capital flows and economic growth was investigated to determine which capital flow contributes most to the economy.

The results obtained from the analysis revealed a uni-directional causality running from economic growth both to debt liabilities and portfolio equity in South Africa, whereas the opposite was the case for foreign direct investment, as a uni-directional causality was seen to run from foreign direct investment to economic growth. The causality between economic growth and remittances was however mixed, as both bi-directional and uni-directional causality were observed. 


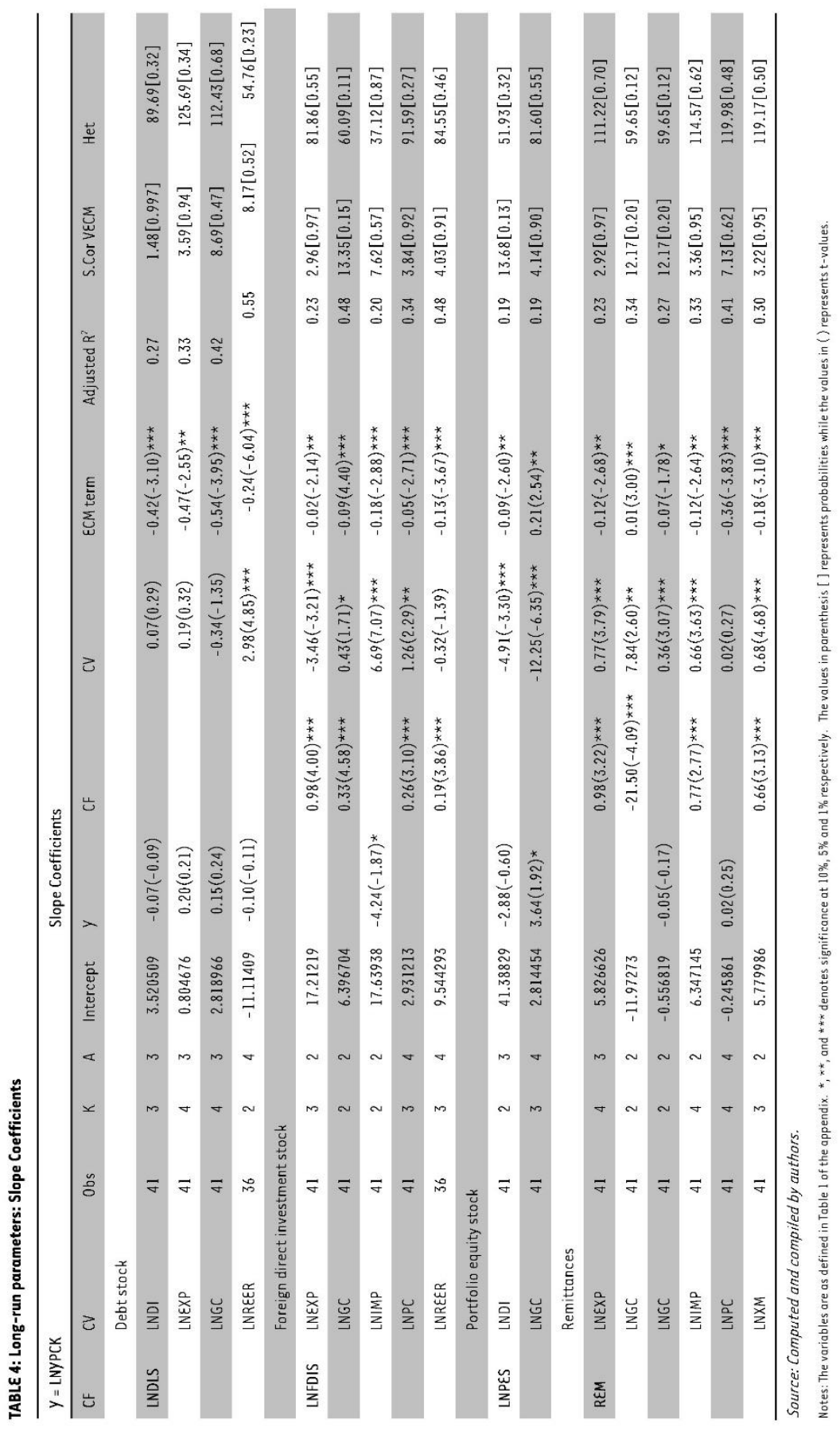


The estimation results revealed that debt liability stock and portfolio equity stock were not significant in determining economic growth in South Africa. From the analysis, foreign direct investment and remittances showed a positive relationship with economic growth. Most of the coefficients were also highly significant (i.e. at the $1 \%$ significance level). Thus, foreign direct investment and remittances contributed more to economic growth than debt liability stock and portfolio equity stock in South Africa during the period of the study.

If policies are to be aimed at stimulating growth in the economy and attracting foreign capital, the South African government is advised to focus on attracting more foreign direct investment and remittances through focused policies that promote the inflow of these types of capital flows.

\section{LIST OF REFERENCES}

Acosta, P., Calderón, C., Fajnzylber, P. \& Lopez, H. (2008). What is the Impact of International Remittances on Poverty and Inequality in Latin America? World Development, 36(1), pp. 89-114.

Adegbite, E.0., Ayadi, F.S. \& Ayadi, O.F. (2008). The Impact of Nigeria's External Debt on Economic Development. International Journal of Emerging Markets, 3(3), pp. 285-301.

Adjasi, C., Abor, J., Osei, K.A. \& Nyavor-Foli, ع.E. (2012). FDI and Economic Activity in Africa: The Role of Local Financial Markets. Thunderbird International Business Review, 54(4), pp. 429-39.

Agbloyor, E.K., Abor, J.Y., Adjasi, C.K.D. \& Yawson, A. (2014). Private Capital Flows and Economic Growth in Africa: The Role of Domestic Financial Markets. Journal of International Financial Markets, Institutions and Money, 30, pp. 137-152.

Aitken, B.J. \& Harrison, A.E. (1999). Do Domestic Firms Benefit from Direct Foreign Investment? Evidence from Venezuela. American Economic Review, 89(3) pp. 605-618.

Aizenman, J., Jinjarak, Y. \& Park, D. (2013). Capital Flows and Economic Growth in the Era of Financial Integration and Crisis, 1990-2010. Open Economies Review, 24(3) pp. 371-396.

Ajayi, L.B. \& Oke, M.O. (2012). Effect of External Debt on Economic Growth and Development of Nigeria. International Journal of Business and Social Science, 3(12), pp. 297-304.

Akram, N. (2013). Empirical Examination of Debt and Growth Nexus in South Asian Countries. Economic development in South and East Asia: empirical examination of East Asian Development Model, 20(2), pp. 29-52.

Alfaro, L., Chanda, A., Kalemli-Ozcan, S. \& Sayek, S. (2004). FDI and Economic Growth: The Role of Local Financial Markets. Journal of International Economics, 64(1), pp. 89-112.

Amuedo-Dorantes, C. \& Pozo, S. (2004). Workers' Remittances and the Real Exchange Rate: A Paradox of Gifts. World Development, 32(8), pp. 1407-1417.

ALMB. (2014). Labour market policy, labour market information and statistics. Annual Labour Market Bulletin (ALMB), Department of Labour, Republic of South Africa, Pretoria. April 2013 - March 2014.

Arestis, P. \& Demetriades, P. (1997). Financial Development and Economic Growth: Assessing the Evidence. The Economic Journal, 107(442), pp. 783-99.

Asteriou, D. (2009). Foreign Aid and Economic Growth: New Evidence from a Panel Data Approach for Five South Asian Countries. Journal of Policy Modeling, 31(1), pp. 155-161. 
Aziakpono, M. (2008). The depth of financial integration and its effects on financial development and economic performance of the SACU countries. Ph.D. thesis, University of the Free State, South Africa.

Bailliu, J.N. (2000). Private Capital Flows, Financial Development, and Economic Growth in Developing Countries. Bank of Canada.

Balasubramanyam, V.N., Salisu, M. \& Sapsford, D. (1996). Foreign Direct Investment and Growth in EP and IS Countries. The Economic Journal, 106(434) pp. 92-105.

Barajas, A., Chami, R., Fullenkamp, C., Gapen, M. \& Montiel, P. (2009). Do workers'remittances promote economic growth? International Monetary Fund Washington, DC.

Baum, A., Checherita-Westphal, C. \& Rother, P. (2013). Debt and Growth: New Evidence for the Euro Area. Journal of International Money and Finance, 32, pp. 809-821.

Bengoa, M. \& Sanchez-Robles, B. (2003). Foreign Direct Investment, Economic Freedom and Growth: New Evidence from Latin America. European Journal of Political Economy, 19(3), pp. 529-545.

Borensztein, E., De Gregorio, J. \& Lee, J. (1998). How does Foreign Direct Investment Affect Economic Growth? Journal of International Economics, 45(1), pp. 115-35.

Buch, C.M. \& Kuckulenz, A. (2004). Worker Remittances and Capital Flows to Developing Countries. ZEW-Centre for European Economic Research Discussion paper, (04-031).

Burnside, C. \& Dollar, D. (2000). Aid, Policies, and Growth. American Economic Review, 90(4)pp. 847868.

Carkovic, M. \& Levine, R. (2002). Does Foreign Direct Investment Accelerate Economic Growth? University of Minnesota Department of Finance Working Paper.

Chami, R., Fullenkamp, C. \& Jahjah, S. (2005). Are Immigrant Remittance Flows a Source of Capital for Development. International Monetary Fund. IMF staff papers, 52(1), pp. 55-81.

Checherita, C. \& Rother, P. (2010). The Impact of High and Growing Government Debt on Economic Growth. An empirical investigation for the Euro Area. Frankfurt: European Central Bank. (Working Paper Series, 1237).

Chenery, H.B. \& Strout, A.M. 1966. Foreign Assistance and Economic Development. The American Economic Review, 56(4), pp. 679-733.

Chinn, M.D. \& Ito, H. (2006). What Matters for Financial Development? Capital Controls, Institutions, and Interactions. Journal of Development Economics, 81(1), pp. 163-92.

Chowdhury, M.B. (2011). Remittances Flow and Financial Development in Bangladesh. Economic Modelling, 28(6), pp. 2600-2608.

De Mello, L. R. (1997). Foreign Direct Investment in Developing Countries and Growth: A Selective Survey. The Journal of Development Studies, 34(1), pp. 1-34.

Demetriades, P.0. \& Hussein, K.A. (1996). Does Financial Development Cause Economic Growth? Time-Series Evidence from 16 Countries. Journal of Development Economics, 51 (2), pp. 387-411.

Demirgüç-Kunt, A. \& Levine, R. (1996). Stock Markets, Corporate Finance, and Economic Growth: An Overview. The World Bank Economic Review, 10(2), pp. 223-39.

Driffield, N. \& Jones, C. (2013). Impact of FDI, ODA and Migrant Remittances on Economic Growth in Developing Countries: A Systems Approach. The European Journal of Development Research, 25(2), pp. 173-96. 
Du Plessis, S. \& Smit, B. (2006). Economic Growth in South Africa since 1994. University of,

Durham, J.B. (2004). Absorptive Capacity and the Effects of Foreign Direct Investment and Equity Foreign Portfolio Investment on Economic Growth. European Economic Review, 48(2), pp. 285-306.

Dzangare, G. (2011). The Impact of Private Capital Flows on Economic Growth in South Africa. Ph.D. thesis, University of Fort Hare, South Africa.

Easterly, W. (2003). Can Foreign Aid Buy Growth? The Journal of Economic Perspectives, 17(3), pp. 2348.

Edison, H.J., Levine, R., Ricci, L. \& Sløk, T. (2002). International Financial Integration and Economic Growth. Journal of International Money and Finance, 21(6), pp. 749-76.

Elbadawi, I. \& Rocha, R.R. (1992). Determinants of Expatriate Workers' Remittances in North Africa and Europe. Country Economics Department, World Bank

Fajnzylber, P. \& López, J.H. (2007). Close to home: The Development impact of Remittances in Latin America. International Bank for Reconstruction and Development

Fayissa, B. \& Nsiah, C. (2010). The Impact of Remittances on Economic Growth and Development in Africa. American Economist, 55(2), pp. 92-103.

Fedderke, J.W. \& Romm, A.T. (2006). Growth Impact and Determinants of Foreign Direct Investment into South Africa, 1956-2003. Economic Modelling, 23(5), pp. 738-760.

Fosu, A.K. (1996). Primary Exports and Economic Growth in Developing Countries. The World Economy, 19(4), pp. 465-475.

Giuliano, P. \& Ruiz-Arranz, M. (2009). Remittances, Financial Development, and Growth. Journal of Development Economics, 90(1), pp. 144-152.

Hansen, H. \& Tarp, F. (2001). Aid and Growth Regressions. Journal of Development Economics, 64(2), pp. 547-570.

Harris, D. (1995). Using Cointegration Analysis in Econometric Modelling. London: Prentice Hall, Harvester Wheatsheaf.

IMF, (2003). Estimation of the Equilibrium Real Exchange Rate for South Africa. IMF Country Report No. 03/18. January 2003. South Africa: Selected Issues (I).

IMF, (2012). Growth resuming, dangers remain. World Economic Outlook, April 2012. International Monetary Fund (IMF).

Johansen, S. (1991). Estimation and Hypothesis Testing of Cointegration Vectors in Gaussian Vector Autoregressive Models. Econometrica: Journal of the Econometric Society, 59(6), pp. 1551-1580.

Johansen, S. (1988). Statistical Analysis of Cointegration Vectors. Journal of Economic Dynamics and Control, 12(2), pp. 231-54.

Johansen, S. \& Juselius, K. (1990). Maximum Likelihood Estimation and Inference on Cointegration with Applications to the Demand for Money. Oxford Bulletin of Economics and Statistics, 52(2), pp. 169-210.

Karras, G. (2006). Foreign Aid and long-run Economic Growth: Empirical Evidence for a Panel of Developing Countries. Journal of International Development, 18(1), pp. 15-28.

King, R.G. \& Levine, R. (1993). Finance and Growth: Schumpeter might be Right. The Quarterly Journal of Economics, 108(3), pp. 717-37. 
Klein, M.W. \& Olivei, G.P. (2008). Capital Account Liberalization, Financial Depth, and Economic Growth. Journal of International Money and Finance, 27(6), pp. 861-75.

Kose, M.A., Prasad, E., Rogoff, K. \& Wei, S. (2009). Financial Globalization: A Reappraisal. IMF Staff Papers, 56(1), pp. 8-62.

Lane, P.R. \& Milesi-Ferretti, G.M. (2007). The External Wealth of Nations Mark II: Revised and Extended Estimates of Foreign Assets and Liabilities, 1970-2004. Journal of International Economics, 73(2), pp. 223-250.

Lartey, દ. K. (2013). Remittances, Investment and Growth in Sub-Saharan Africa. The Journal of International Trade \& Economic Development, 22(7), pp. 1038-1058.

Lensink, R. \& Morrissey, 0. (2006). Foreign Direct Investment: Flows, Volatility, and the Impact on Growth*. Review of International Economics, 14(3), pp. 478-493.

Levine, R. \& Zervos, S. (1998). Stock Markets, Banks, and Economic Growth. American Economic Review, 88(3), pp. 537-558.

Macias, J.B. \& Massa, I. (2009). The Global Financial Crisis and Sub-Saharan Africa: The Effects of Slowing Private Capital Inflows on Growth. Overseas Development Institute (ODI), 111 Westminster Bridge Road London. (Working paper 304).

Morrissey, 0. (2001). Does aid increase growth? Progress in Development Studies, 1(1), pp. 37-50.

Mosley, P., Hudson, J. \& Horrell, S. (1987). Aid, the Public Sector and the Market in Less Developed Countries. The Economic Journal, 97(387), pp. 616-641.

Murshid, A.P. \& Mody, A. (2011). Growth from International Capital Flows: The Role of Volatility Regimes. International Monetary Fund, IMF. (Working paper, WP/11/90).

Ndikumana, L. \& Boyce, J.K. (2003). Public Debts and Private Assets: Explaining Capital Flight from Sub-Saharan African Countries. World Development, 31(1), pp. 107-130.

Pagano, M. (1993). Financial Markets and Growth: An Overview. European Economic Review, 37(2), pp. 613-22.

Papanek, G.F. (1973). Aid, Foreign Private Investment, Savings, and Growth in Less Developed Countries. The Journal of Political Economy, 81 (1), pp. 120-130.

Pattillo, C.A., Poirson, H. \& Ricci, L.A. (2002). External debt and growth. International Monetary Fund Quinn, D.P. \& Toyoda, A.M. (2008). Does Capital Account Liberalization Lead to Growth? Review of Financial Studies, 21(3), pp. 1403-1449.

Rajan, R.G. \& Subramanian, A. (2008). Aid and Growth: What does the Cross-Country Evidence really show? The review of economics and statistics, 90(4), pp. 643-665.

Reinhart, C.M. \& Rogoff, K.S. (2010). Growth in a Time of Debt, (No. w15639) National Bureau of Economic Research.

Reisen, H. \& Soto, M. (2001). Which Types of Capital Inflows Foster Developing-Country Growth? International Finance, 4(1), pp. 1-14.

Republic of South Africa (RSA), (2014). State of the Nation Address 17 June, 2014. Available: http://www.gov.za/state-nation-address-his-excellency-jacob-g-zuma-president-republic-southafrica-occasion-june-2014. (Accessed 19 June, 2014).). 
Seddighi, H., Lawler, K. A., \& Katos, A. V. (2000). Econometrics: A Practical Approach. Psychology Press.

Trading economics, (2016). South Africa. Available: http://www.tradingeconomics.com/southafrica/currency. (Accessed 18 January, 2016).

Tswamuno, D.T., Pardee, S. \& Wunnava, P.V. (2007). Financial Liberalization and Economic Growth: Lessons from the South African Experience. International Journal of Applied Economics, 4(2), pp. 75 89.

Wesso, G.R. (2001). The Dynamics of capital flows in South Africa: An empirical investigation. South African Reserve Bank (SARB) Quarterly Bulletin, June 2001. South Africa.

World Bank (2011). World Bank World Development Indicators (WDI). Washington D.C. World Bank. World Bank (2013). World Bank Global Financial Development Database (GFDD). Washington D.C. World Bank.

World Bank (2014). World Bank World Development Indicators (WDI). Washington D.C. World Bank. World Bank (2015). World Bank World Development Indicators (WDI). Washington D.C. World Bank. Zhou, S. (2003). Interest rate linkages within the European Monetary System: new evidence incorporating long-run trends. Journal of International Money and Finance, 22(4), pp. 571-590. 